\title{
Pengaruh Politik Dalam Birokrasi Pemerintahan
}

\author{
${ }^{1}$ Bambang Agus Diana \\ ${ }^{1}$ Universitas Terbuka, Indonesia; tolloheor@yahoo.co.id
}

\begin{abstract}
Public Management is a management organization that is formed to achieve goals by coordinating the various interests of many people in a system and administrative pattern. So bureaucratic organizations are activities that require close coordination of activities involving a large number of people and are very structured in the process of implementing government. Increased bureaucracy must be supported by the people above who run the government and not only on the system, as well as any system or rules that are made, if only the people who run the system do not have the ability, and are consistent with their work or devices will be as expected. The public view, bureaucracy is closely related to the problem of service, orderly, systematic, both from the central government to the village level government. The real purpose of bureaucracy is that every public service need can be resolved quickly. Increasing government bureaucracy must be created through healthy apparatus both physically and spiritually (morality). The hope of the community for the bureaucracy is served well and quickly, without convolution with good service, it will accelerate the realization of the goals and aspirations of the people. Politics is an instrument for realizing community goals, namely through government bureaucracy, which results from the political process. The purpose of this paper is to provide a view of the political influence of reforming government bureaucracy. The conclusion is that if public services can be done well through government bureaucracy, then that must be the condition of the implementing government apparatus in addition to having human resources that are in accordance with a morally healthy body.
\end{abstract}

Keywords: Bureaucracy, Politics, Public Administration, Management.

\section{Pendahuluan}

Manajemen publik dengan birokrasi merupakan dua elemen penting yang tidak dapat dipisahkan dari kegiatan pemerintahan dalam upaya mengatur dan menjalankan roda pemerintahan, karena birokrasi merupakan perwujudan dari manajemen publik. Hal tersebut merupakan kewajiban pemerintah yang harus dilakukan dalam mencapai suatu tujuan dan kepentingan, baik tujuan dan kepentingan organisasi pemerintah maupun tujuan dan kepentingan masyarakat. Birokrasi itu sendiri terkait erat dengan layanan publik. Istilah Birokrasi tidak hanya dikenal di dunia pemerintahan saja akan tetapi pada bidang-bidang lainnya, seperti militer, dan organisasi swasta lainnya termasuk dunia bisnis. Birokrasi adalah wadah organisasi yang sengaja dibentuk sebagai bagian dari manajemen organisasi yang menjalankan aktivitasnya untuk mencapai tujuan dengan mengkoordinasikan beragam kepentingan orang dalam suatu sistem dan pola administrasi. Jadi organisasi birokrasi adalah kegiatan yang membutuhkan koordinasi dimana kegiatannya melibatkan banyak orang dan sangat terspesialisasi.

Ketergantungan masyarakat pada birokrasi masih sangat besar, namun peran birokrasi di Indonesia saat ini tidak optimal dari periode ke periode pemerintahan, belum ada kemajuan yang signifikan. Peran birokrasi atau manajemen publik harus terlepas dari pengaruh politik, tetapi dalam kenyataannya birokrasi tampaknya sangat melekat pada pengaruh politik, birokrasi Indonesia seperti dibawa oleh angin politik dan pemerintahan, setiap pemimpin harus memiliki perubahan gaya birokrasi, birokrasi tidak bisa merujuk pada kebaikan yang lebih lama, tetapi tolok ukur adalah kepemimpinan puncak sebagai pemimpin yang akan mempengaruhi proses birokrasi. Pengangkatan karyawan baru bukanlah solusi untuk meningkatkan birokrasi tetapi justru akan membuat organisasi menjadi lebih gemuk dengan 
banyak karyawan tetapi kurang bekerja dan ini akan mengarah pada efisiensi dan ketidak efektifan yang akan mengarah pada jalur kegiatan yang semakin lama berjalan, terutama dalam pelayanan publik pemerintah.

Peningkatan Birokrasi harus didukung oleh orang-orang di atas yang menjalankan pemerintahan dan tidak hanya pada sistem, serta sistem atau aturan apa pun yang dibuat, jika saja orang yang menjalankan sistem tidak memiliki kemampuan, dan konsistensi serta komitmen agar pekerjaan benar-benar akan merusak sistem atau perangkat yang ada, hasilnya tidak akan seperti yang diharapkan. Apa yang dikatakan oleh Weber (1947), bahwa birokrasi yang ideal didasarkan pada hubungan antara wewenang untuk menempatkan dan menunjuk karyawan bawahan dengan menentukan tugas dan kewajiban masing-masing dan pesanan dilakukan secara tertulis, pengaturan dan promosi personel berdasarkan aturan tertentu (2011: 51). Jika diteliti bahwa birokrasi dan manajemen pemerintah adalah alat implementasi politik, dan dari politik untuk berkumpul menjadi birokrasi, jika perayaan politik selesai maka birokrasi pemerintah akan muncul, gaya birokrasi pemerintah dapat berubah sesuai dengan karakter kepemimpinan puncaknya.

Birokrasi dan Politik akan berjalan beriringan dan diharapkan menjadi kerja tim dalam administrasi pemerintahan, khususnya Negara Indonesia, tetapi antara birokrasi dan kepentingan politik harus dipisahkan. menyusun birokrasi di Indonesia disamakan dengan rumah atau kantor yang memiliki satu pintu di mana ketika kita telah memasuki rumah atau kantor kita dapat melakukan berbagai kegiatan sehingga jika kunci rumah atau kantor rusak kita tidak dapat memasuki rumah karena hanya memiliki satu door (pemerintah), artinya jika Anda ingin masuk, anda harus mengganti atau memperbaiki kunci. Contoh lainnya adalah KTP merupakan hasil dari layanan birokrasi yang dapat digunakan untuk berbagai macam hal yang berkaitan dengan pendokumentasian, identitas, data data yang dibutuhkan dalam berbagai aktifitas, dan lain-lain. Oleh karena itu, disadari atau tidak bahwa kehidupan manusia sejak lahir sampai mati tidak dapat dipisahkan dari birokrasi pemerintah.

Selama ini masyarakat selalu memandang bahwa birokrasi erat kaitannya dengan masalah pelayanan yang tertib, sistematis, baik dari pemerintah pusat hingga pemerintah tingkat desa, namun pada kenyataanya masih belum bisa diharapkan. Tujuan yang diharapkan oleh masyarakat dari birokrasi adalah adanya pelayanan yang lebih baik dan cepat. Sehingga upaya yang harus dilakukan para birokrat adalah mengkoordinasikan pelayanan ke sejumlah pegawai agar semua layanan masyarkat tidak menumpuk dalam satu orang saja, sehingga dengan demikian jelas bahwa birokrasi juga dipastikan terkait erat dengan administrasi. Namun pada kenyataannya birokrasi di negara kita jauh dari yang diharapkan, selain rumit dan juga memakan waktu yang cukup lama, tidak jelas, kaku tidak jarang pelayan menunjuk ke siapa petugas pelayanan, penuh korupsi dan kolusi.

Birokrasi saat ini menunjukkan irasionalitas layanan, dan tidak mendukung sikap ramah terhadap masyarakat. Ini berarti bahwa petugas birokrat berlaku acuh tak acuh terhadap kebutuhan masyarakat, yang pada akhirnya mengumpulkan masyarakat untuk mendapatkan layanan. Ini menunjukkan bahwa birokrasi masih berupa penguasa daripada pelayan publik dan jauh dari pemahaman yang sebenarnya. Dan justru birokrasi masih berpihak pada pejabat misalnya jika seorang pejabat (penguasa) mengurus kebutuhan administrasi, maka petugas layanan cepat menyelesaikan layanan administrasi tanpa menunda penundaan, bahkan jika ia harus melewati antrian panjang. Dan jika dilihat dari aspek kebiasaan birokrasi, aparatur birokrasi biasanya memiliki status sosial yang tinggi di masyarakat. Status sosial ini seringkali dijadikan aset kekuasaan yang menjadikan yang disegani, karena orang cenderung tunduk dan menghormati kepada mereka yang memiliki status sosial yang lebih tinggi. Ini adalah salah satu contoh fenomena buruk dan ketidakkonsistenan birokrat terhadap apa yang mereka 
pegang, yaitu sebagai pelayan bagi bangsa dan rakyatnya. Berdasarkan pada latar belakang tersebut, maka peneliti kemudian merasa tertarik untuk mengangkat sebuah penelitian dengan tujuan yaitu untuk menganalisis bagaimana gambaran pengaruh kekuatan politik terhadap realisasi reformasi birokrasi pemerintah.

\section{Metode Penelitian}

Tulisan ini bersumber dari hasil analisis buku-buku atau, yang membahas terkait dengan birokrasi, politik dan pemerintahan selain itu penulis mendapatkan sumber juga dari jurnal-jurnal dan media online, maupun media tulis yang membahas terkait birokrasi, layanan publik oleh pemerintahan, data literatur ini selanjutnya dibuat menjadi bahan kajian penelitian. Selain itu penulis mendapatkan data primer berupa wawancara secara langsung sistem reformasi birokrasi karena ini biasanya akan menjadi acauan utama bagi implementasi sistem reformasi birokrasi sehingga dapat diimplementasikan dengan baik dalam mewujudkan "Good Governance". terkait dengan birokrasi pemerintahan dan layanan dari sejumlah responden masyarakat sebagai pengguna layanan publik serta pegawai pemerintah sebagai publik service. Kemudian Data/ sumber tulisan yang diperoleh dikompulasi, dianalisis, dan disimpulkan sehingga mendapatkan kesimpulan mengenai studi literatur.

\section{Hasil dan Pembahasan}

Selama ini peran daripada manajemen publik akan sangat erat hubungannya dengan administrasi publik karena keduanya saling keterkaitan satu sama lain. Dimana administrasi adalah sesuatu merupakan kegiatan yang dilakukan secara konseptual yang dapat menentukan tujuan kebijakan umum secara keseluruhan sedangkan manajemen sebagai bagian dari konsep yang bertugas menjalankan seluruh aktivitas dalam rangka mencapai tujuan sesuai kebijakan tertentu di tingkat administrasi. Oleh karena itu bahwa seorang pemimpin bukan hanya cerdas saja tetapi dituntut mampu membuat perencanaan, pengendalian, mengkoordinasikan sampai pengawasan berbagai kegiatan organisasinya dalam rangka menjalankan tugas kepemimpinannya, sehingga semua kegiatan dalam organisasi dapat berlangsung dengan baik, seperti salah satu contohnya dalam organisasi pemerintah yang selalu dikaitkan dengan layanan publik, di mana birokrasi layanan di negara kita dipandang sebagai birokrasi yang panjang dan berbelit-belit yang menyebabkan orang enggan berurusan dengan birokrasi yang cukup rumit dan penuh kolusi, hal-hal demikian merupakan respon yang wajar dari masyarakat karena memang dalam kenyataannya tidak jauh dari kenyataanya.

Karena itu kepemimpinan suatu pemerintahan / lembaga birokrasi harus konsisten dengan aturan, mampu mengendalikan bawahan, karena jabatan itu merupakan amanah yang harus dikerjakan dengan baik untuk rakyat bangsa dan negara. Seperti yang dinyatakan di atas, sebagai hasil dari layanan yang lama, orang sering mengambil jalan pintas, yaitu dengan menyuap atau menggunakan uang rokok sehingga layanan cepat selesai tanpa harus menunggu atau menunggu lama. Kepemimpinan harus tegas tentang staf yang diketahui melakukan hal seperti itu, selain itu kepemimpinan harus mampu mengelola layanan yang sederhana dan praktis untuk mempermudah orang yang membutuhkan layanan administrasi pemerintah, karena layanan publik adalah suatu kegiatan moral yang perlu dipertanggungjawabkan kepada pemerintah maupun masyarakat pada umumnya.

Selanjutnya, menurut Dwijowiyoto (2001), menyatakan kondisi riil birokrasi Indonesia saat ini, digambarkan sebagai berikut

1. Secara umum, ukuran keberhasilan birokrasi itu sendiri tidak sesuai dengan tuntutan organisasi yang baru. Di Indonesia, birokrasi di departemen atau pemerintah adalah yang 
terendah, yang memprioritaskan input dan proses, bukan hasil. Karena itu, yang selalu dipertimbangkan oleh birokrasi adalah tidak ada istirahat di akhir tahun .

2. Birokrasi kita tidak pernah menyadari bahwa ada perubahan besar di dunia. Bahwa saat ini ini di era globalisasi segala sesuatu akan sangat tergantung kepada permintaan pasar terutama masalah bisnis, oleh karena itu jika saja ingin berhasil dan mampu bersaing maka harus mampu pula melayani konsumen atau pelanggan. Dalam hal ini pasar pangsa birokrasi adalah seluruh kominitas yang memerlukan pelayanan, bukan saja sekelompok orang, pejabat pemerintahan dalam birokrasi sendiri tetapi seluruh masyarakat yang ada.

(http://www.administrasipublik.com/2014/09/kondisi-reformasi-birokrasi-di-indonesia-saatini.html).

Sebagai salah satu negara yang masih berkembang khususnya dikawasan Asia tenggara, Indonesia memiliki jumlah penduduk terbanyak masih memiliki beberapa permasalahan di mana populasi dan sumber daya manusia sangat kompleks, selain itu masih banyaknya bidang pekerjaan yang tidak sesuai pendidikan dan keahlian yang dimiliki, sehingga hal tersebut akan mempengaruhi kemampuan dan keahlian mereka. Dalam era serba digital yang berbasis komputer dan Internet maka dalam upaya meningkatkan layanan birokrasi yang baik harus didukung oleh kemampuan dan keahlian sumber daya manusia yang berkualitas, serta prinsip birokrat yang terutama memberikan pelayanan yang baik kepada masyarakat. Menurut Heady (1989) ada tiga macam pendekatan dalam merumuskan birokrasi yaitu a) pendekatan struktural, b) pendekatan perilaku, dan c) pendekatan untuk mencapai tujuan.

Pendekatan struktural pertama adalah kecenderungan yang paling dominan, yang menganggap birokrasi sebagai pengaturan yang terdiri dari hierarki otoritas dan pembagian kerja yang sangat rinci, sedangkan pendekatan kedua bermaksud untuk membentuk birokrasi dalam pendekatan perilaku, kecenderungan kedua ini sering dipahami untuk menambah perilaku. karakteristik pada karakteristik struktural birokrasi struktural birokrasi. Sedangkan pendekatan ketiga, seperti yang dikatakan Blau \& Scott (1962), mendefinisikan birokrasi dalam hal mencapai tujuan organisasi. Dalam pemikiran birokrasi seperti organisasi yang memaksimalkan efisiensi dalam administrasi atau mode pelembagaan perilaku sosial yang terorganisir dalam rangka mencapai efisiensi administrasi. (Mufiz, 2011).

Jika dilihat dari sudut pandang politik, menurut Budiardjo (2012) politik selalu menyangkut tujuan semua orang (tujuan publik) dan bukan tujuan pribadi. Oleh sebab itu dapat kita pahami bahwa politik yang dilakukan oleh suatu negara harus memiliki tujuan yaitu mensejahterakan rakyat dan tidak hanya untuk menguntungkan satu pihak atau kelompok saja. Singkatnya, politik adalah instrumen untuk mewujudkan tujuan seluruh warga negaranya. Konsep utama yang terkait dengan politik adalah: 1. Negara 2. Kekuatan 3. Pengambilan keputusan 4. Kebijakan (kebijakan) 5. Distribusi (alokasi) atau alokasi (alokasi) kekuatan Selain itu, menurut Weber, birokrasi mendasarkan dirinya pada hubungan antara wewenang untuk menempatkan dan menunjuk karyawan bawahan dengan menentukan tugas tugas masing-masing, dan pesanan yang dibuat secara tertulis dan pengaturan mengenai hubungan wewenang dan promosi personil berdasarkan tertentu aturan. (Mufiz, 2011).

Weber (1947) mengungkapkan tipe birokrasi ideal yang menurutnya terdiri dari: (1). Ada prinsip penugasan tugas yang jelas dari penugasan reguler yang umumnya diatur oleh hukum atau peraturan administrasi, sebagai berikut: Sebuah. pembagian tugas yang jelas untuk aparatur birokrasi b. Ada pendelegasian wewenang untuk pejabat organisasi c. keberadaan keahlian dalam setiap tugas. (2). Keberadaan Prinsip Hirarkhi berarti bahwa tugas dan wewenang dalam organisasi diatur dan didelegasikan secara bertahap. (3). Manajemen Kantor Modern didasarkan pada dokumen tertulis atau arsip. (4). penugasan tugas dalam organisasi 
dilakukan berdasarkan spesialisasi, maka diperlukan pendidikan dan pelatihan bagi karyawan/birokrasi secara terus menerus. (5). Jika organisasi telah berkembang, kegiatan kantor mengharuskan karyawan untuk bekerja dengan kapasitas penuh. (6). Oleh karena itu, setiap tindakan dalam birokrasi didasarkan pada hukum dan peraturan yang ada, sehingga setiap aparatur birokrasi harus mengetahui, memahami, dan mempraktikkan hukum dan peraturan tersebut. (Mufiz, 2011).

Dari uraian pandangan tentang masalah birokrasi di atas, birokrasi nampaknya telah menjadi pelayan untuk kepentingan sekelompok orang atau kepentingan politik dan tidak lagi menjadi tempat atau jembatan untuk kepentingan rakyat. Dimana birokrasi sering digunakan sebagai alat untuk mempertahankan politik dan tidak lagi menjadi alat untuk kepentingan rakyat, karena tidak sedikit pemimpin birokrasi berasal dari partai politik, sehingga bayangan kekuasaan dalam politik tampaknya menjadi tempat dan strategi dalam menjalankan kekuatannya. Reformasi birokrasi membentang seolah-olah mereka tidak mampu menembus situasi politik tanah air yang sejauh ini sehingga birokrasi di negara kita begitu mudah terbawa oleh situasi dan kondisi politik tanah air, baik di daerah maupun di pusat pemerintahan. Karena pada kenyataannya, mayoritas pemimpin baik pemerintah daerah maupun pusat kebanyakan dari organisasi politik. Jadi timbul pertanyaan secara tidak langsung, apakah birokrasi itu hasil dari partai politik atau birokrasi yang menghasilkan partai politik? sejalan dengan hal tersebut, bahwa pada dasarnya birokrasi adalah hasil dari suatu pemerintahan, dan fakta bahwa pemerintah adalah hasil dari suatu peristiwa politik. Oleh karena itu, birokrasi Indonesia saat ini tidak dapat dipisahkan pengaruh politik yang berkembang terutama dari partai yang berkuasa, dimana para pemimpin daerah hingga pusat adalah hasil dari suara politikmaka tidak heran apabila kebijakan birokrat terkadang dipengaruhi oleh latar belakang dan budaya politik masing-masing yang dapat menyebabkan birokrasi pemerintah menjadi terfragmentasi.

Kepemimpinan politik di tingkat puncak departemen bisa menanamkan pengaruh hingga tingkat staf. Karyawan cenderung tidak netral dan mengikuti pilihan politik kepemimpinan. Akibatnya, orientasi karyawan tidak terfokus pada layanan publik yang independen, tetapi disertai dengan kepentingan politik tertentu. Biasanya pada sistem pemerintahan yang menganut sistem demokrasi, adanya pengaruh politik dalam birokrasi pemerintahan tidak dapat dihindari, karena kemenangan sebuah partai politik dipastikan akan mengubah orang-orang didalamnya termasuk yang memberikan kebijakan tergantung dari partai mana mereka berasal serta latar belaknag visi-misi yang mereka usung, oleh karena itu biasanya akan muncul sistem atau gagasan baru yang akan mengubah kebijakan sebelumnya. Menurut Thoha (2007), birokrasi pemerintah tidak dapat dipisahkan dari proses dan kegiatan politik. Politik terdiri dari orang-orang yang berperilaku dan bertindak secara politis, yang secara politis diorganisir oleh kelompok-kelompok kepentingan dan mencoba mempengaruhi pemerintah untuk mengambil dan menerapkan kebijakan dan tindakan yang dapat meningkatkan kepentingan mereka dan mengesampingkan kepentingan kelompok lain.

Harapan masyarakat akan birokrasi dilayani dengan baik dan cepat, tanpa berbelitbelit dengan pelayanan yang baik, itu akan mempercepat realisasi tujuan dan aspirasi rakyat. Politik merupakan salah satu alat untuk untuk mewujudkan tujuan-tujuan kelompoknya, yaitu, melalui birokrasi pemerintah, yang dihasilkan dari proses politik. Namun dalam kenyataannya politik terkadang menghambat masyarakat dalam mewujudkan tujuan. Walaupun selama ini masyarakat dipastikan selalu terlibat dalam proses politik di negara ini seperti Pemilihan Umum (Pemilu), namun kebijakan yang dikeluarkan pemerintah seringkali diadopsi oleh para penguasa, yang sebagian besar para penguasa tersebut berasal dari berbagai organisasi politik yang terkadang tidak selalu berpihak pada rakyat. Tentu saja hal ini membuat rakyat kecewa dan ketidakpercayaan pada para penguasa juga meningkat karena melalui kebijakan birokrasi yang dikeluarkan umumnya kurang memihak kepada rakyat. 
Pada umumnya, apapun itu yang dilakukan oleh bawahan merupakan hasil dari apa yang menjadi kebijakan penguasa atau pimpinannya. Memang benar apa yang dikatakan Thoha (2007) bahwa kehadiran partai politik dalam suatu sistem pemerintahan akan mempengaruhi tatanan birokrasi pemerintah. Upaya meningkatkan birokrasi melalui kinerja petugas yang sehat dan bermoral Sebuah fenomena yang kontradiktif di negara ini, di mana di Indonesia adalah negara yang dihuni oleh komunitas agama, dan itu muncul, karena setiap warga menyatakan agamanya sebagaimana tercantum dalam KTP. Namun dalam kenyataannya hanya ada beberapa kelompok kecil bahkan seorang pejabat. Siapa yang tidak ingin tahu pentingnya moralitas. Sekecil apa pun pelanggaran moral dapat dilakukan berulang kali dapat mengurangi sendi-sendi sendi pribadi bangsa. Demikian juga apa yang dilakukan oleh segelintir aparat birokrasi Negara, betapapun kecilnya itu dilakukan dan jika diulangi berulang kali, negara ini akan tetap dibubarkan dalam kesengsaraan. Kualitas suatu bangsa akan ditentukan oleh rakyatnya dan aparatur negara itu sendiri baik dari segi kualitas sumber dayanya maupun kualitas moralnya.

Keberadaan birokrasi dalam sistem pemerintahan memiliki posisi dan peran yang sangat strategis. Karena kita ketahui bahwa birokrasi menjalankan dan mengendalikan banyak aspek kehidupan masyarakat. Mulai dari masalah kelahiran, pernikahan, perceraian, perizinan usaha hingga urusan kematian, dan lain-lain, masyarakat tidak bisa menghindari birorkasi. Ketergantungan masyarakat itu sendiri pada birokrasi masih sangat besar. Sehingga jika ingin menciptakan aparatur birokrasi yang bertanggung jawab dan konsisten, pemerintah harus benar-benar menjadi institusi yang dihuni oleh pejabat aparatur yang berkualifikas, baik dari sisi kualitas sumber daya manusianya maupun segi moralitasnya. Oleh karena itu harus dipastikan dalam setiap rekruitmen pegawai pemerintahan, baik Lembaga maupun Non Lembaga/Instansi/ Departemen pemerintahan, harus memiliki kualitas sumber daya manusia yang mumpuni sesuai dengan kebutuhannya, selain itu juga memiliki kualitas moral yang baik yang mampu mengendalikan diri dari segala sesuatu yang dapat mengganggu/merusak pelaksanaan tugas Negara.

Melalui moral aparatur yang sehat, maka akan dihasilkan kinerja birokrasi yang sehat, artinya segala yang dilakukan adalah hasil pemikiran yang jernih, dan dapat dipertanggungjawabkan sesuai dengan prosedur, tidak melakukan penyimpangan (KKN) dalam mencapai maksud dan tujuannya. Apabila aparatur pemerintah berkinerja baik dalam melaksanakan tugsanya maka dapat menciptakan lingkungan, budaya kerja serta tata pemerintahan yang baik pula, karena itu kemajuan sebuah pemerintahan akan sangat tergantung dari aparaturnya sendiri, yaitu sehat secara moral dan sumber daya manusia yang berkualitas pada bidangnya. Kualitas sumber daya manusia saja tidak menjamin perilaku seseorang jika mereka tidak memiliki moral yang baik. Konsistensi dan komitmen pemerintah dalam melakukan pekerjaan tentu akan dilakukan jika aparatur atau pelayan negara mereka memiliki moral yang sehat. Jadi konsistensi kerja akan tercipta jika karyawan atau pejabat memiliki moral yang sehat. Dengan demikian timbul rasa tanggung jawab, hati nurani, dan pikiran yang cerdas untuk selalu jujur dan berpikir positif dalam menjalankan tugas pekerjaannya. Karena kita tahu dengan jelas bahwa visi birokrasi ini adalah perwujudan pemerintahan yang dapat dipercaya atau perwujudan pemerintahan yang baik. 


\section{Simpulan}

Pelaksanaan perubahan birokrasi tidak terlepas dari visi implementasi sistem reformasi birokrasi karena ini biasanya akan menjadi acauan utama bagi implementasi sistem reformasi birokrasi. Dapat dikatakan bahwa hubungan antara birokrasi dan politik memang tidak dapat dipisahkan karena merupakan rangkaian mobil kereta yang saling terkait dan tidak dapat dipisahkan sehingga administrasi birokrasi pemerintah adalah seri dari suatu perjalanan politik. Jadi ketika organisasi suatu partai menjadi penguasa pemerintah, kondisi dan metode menjalankan pemerintahan berbeda sehingga secara otomatis dapat mempengaruhi sistem birokrasi pemerintah dan seringkali sistem yang dianggap baik digantikan oleh sistem baru, ini tidak lain adalah penggantian kepemimpinan birokrat. Birokrasi tidak akan steril dari pengaruh politik sebelum sumber daya manusianya dapat melepaskan atau memisahkan antara kepentingan politik baik kepentingan pribadi maupun kelompok dengan kepentingan rakyat bangsa dan negara, karena mayoritas penguasa lahir dari organisasi politik. Netralitas birokrasi harus ditafsirkan sebagai posisi birokrasi pemerintah yang tidak memihak atau sengaja dibuat demi satu kekuatan politik atau partai politik.

\section{Referensi}

Budiardjo, M. (2012). Dasar-Dasar Ilmu Politik. Jakarta: Gramedia Pustaka Utama Mufiz, A. (2011) Pengantar Ilmu Administrasi Negara. Jakarta: Universitas Terbuka Mustafa, D. (2014). Birokrasi Pemerintahan (Edisi Revisi). Bandung: Alfabeta

Pasolong, H. (2011), Teori Administrasi Publik. Bandung:PT. Alfabeta

Poespoprojo, W. (1998). Filsafat Moral. Bandung: CV Pustaka Grafika

Thoha, M. (2007). Birokrasi dan Politik di Indonesia. Jakarta: PT Raja Grafindo Persada Birokrasi Yang Memihak Rakyat. TIRAS No.13/Th.I. 27 April 1995

Wahab, S.A. (2000). Globalisasi dan Pelayanan Publik, Perspektif Teori Governance. Jurnal Administrasi Negara Vol.II No.1, September 2001:43-58

http://ariyantosospol.blogspot.com/2012/05/pola-hubungan-politik-dan-birokrasi-di.html http://www.administrasipublik.com/2014/09/kondisi-reformasi-birokrasi-di-indonesia-saatini.html Wikipedia bahasa Indonesia, Ensiklopedia Gratis. (2010). Moral. [On line].

http://www.academia.edu/9880774/Birokrasi_indonesia

https://rushdyms.wordpress.com/2011/02/23/perkembangan-birokrasi-di-indonesial 